\title{
The relationship of intrathecal immunoglobulin levels with clinic symptoms and prognosis for acute phase ischemic stroke patients
}

\author{
Akut dönem iskemik inmeli hastalarda intratekal immunglobulin düzeyinin \\ klinik bulgular ve prognozla ilişkisi
}

\author{
Aslı Bolayır*, Hesna Bektaş, Zeynep Issı, Fatma Ayşen Eren, Selvi Okundu \\ Neurology Clinic (A. Bolayır, MD), Zile State Hospital, TR-60400 Tokat, Department of \\ Neurology (H. Bektaş, MD, S. Okundu, MD), Atatürk Training and Research Hospital, TR-06800 \\ Ankara, Neurology Clinic (Z. Iss1, MD), Kars State Hospital, TR-36000 Kars, Neurology Clinic \\ (F. A. Eren, MD), Aksaray State Hospital, TR-68200 Aksaray
}

\begin{abstract}
Aim. Ischemic strokes are about $80-85 \%$ of the strokes, third common cause of mortality in the world. Due to ischemia, neurons are damaged, blood brain barrier (BBB) is disrupted and inflammation is triggered. Although the cell mediated immun response in ischemic stroke has been showed by previous studies,there is no excessive database is available for humoral immun response. In this study, we aim to determine presence and amount of intrathecal immunglobulins after ischemic strokes as a result of humoral immun response in patients with the first and recurrent ischemic stroke. Thus, we could elucidate the presence of humoral immune response effect in long-term prognosis of ischemic stroke. Methods. In this study, 51 patient were included. 32 patients had first and 19 patients had recurrent ischemic stroke. Cerebrospinal fluid (CSF) samples were taken within 72 hours from the symptoms onset by lomber punction. Cell count, CSF Ig G, M, A and microalbumin levels were assessed in CSF samples, also serum Ig G, M, A and albumin levels were measured simultaneously. Albumin and Ig G index and CSF Ig G/CSF albumin ratios were calculated. Infarct volumes of the patients were calculated from computed cranial tomography (CCT) and/or magnetic resonance diffusion weighted imaging (DW MRI). Glasgow Coma Scale (GCS) and National İnstitutes of Health Stroke Scale (NIHSS) were used at the admission, modified Rankin Scale (MRS),Barthel index (BI) and NIHSS were used at the time of discharge from the hospital. Results. Albumin index was normal in the patients with their first ischemic stroke but slightly elevated in the recurrent ischemic stroke group. The CSF Ig G levels $(\mathrm{p}<0.001)$, CSF Ig G/CSF albumin ratio $(0.32 \pm 0.04)$ and CSF Ig G index, $(1.13 \pm 0.16)$ were higher in the recurrent ischemic stroke group. Also unlike the first group, in the recurrent ischemic stroke, there was a a significant positive correlation between the infarct volumes and levels of $\operatorname{IgG}$ $(\mathrm{p}<0.001)$. Considering to MRS and BI, MRS was higher in recurrent ischemic stroke group $(\mathrm{p}=0.001)$ and Barthel index was lower $(\mathrm{p}=0.009)$. Conclusion. Our results showed the intrathecal synthesis of $\mathrm{IgG}$ in recurrent ischemic stroke and the role of humoral immune system in the pathophysiology of recurrent ischemic stroke. However the effect of humoral immune system on the patients'clinic, the prognosis of stroke and disability due to stroke is contraversial.
\end{abstract}

Keywords: Ischemic stroke, cerebrospinal fluid, blood brain barrier, intrathecal immunoglobulin synthesis, humoral immune system, inflamation

Özet

Amaç. İskemik inme, dünya genelinde mortalitenin 3. en sık nedeni olan inmenin, yaklaşık \%8085 'ini oluşturur. İskemiye bağlı olarak nöronlarda yıkım meydana gelir, kan beyin bariyeri(KBB) bozulur ve inflamasyon tetiklenir. İskemik inmede hücresel immün yanıtın rolü önceki çalışmalarda gösterilmiş olup humoral immun yanıtla ilgili oldukça sınırlı sayıda veri mevcuttur. $\mathrm{Bu}$ çalışmayla iskemik inmeli hastalarda humoral immun cevabın sonucu olarak intratekal sentezlenen immunglobulinlerin varlığını ve miktarını saptamayı amaçlıyoruz. Böylece, iskemik inmenin uzun dönem prognozu üzerinde humoral immun cevabın etkisinin varlığına 1 şı tutabiliriz. Yöntem. Bu çalışmaya, 32 ilk ve 19 tekrarlayan iskemik inme atağı geçiren ve şikayetlerinin başladığı andan itibaren ilk 72 saat içinde lomber ponksiyonla beyin omurilik sıvısı 
(BOS) örneği alınan toplam 51 hasta dahil edildi. Alınan BOS örneklerinden hücre sayısı, Ig G, M, A ve mikroalbumin düzeyleri, eş zamanlı alınan serumdan ise Ig G,M,A ve albumin düzeyleri ölçüldü. Albumin ve Ig G indeksi ile BOS Ig G/BOS albumin oranları hesaplandı. Hastaların çekilen bilgisayarlı beyin tomografisi (BBT) ve/veya difüzyon ağırlıklı manyetik rezonans görüntülemelerinden (DA MRG) infarkt hacmi hesaplandı. Hastalara servise yatışında Glaskow koma skalası (GKS), National Institutes of Health Stroke Scale (NIHSS); taburcu olurken ise NIHSS, modifiye Rankin skalası (MRS) ve Barthel indeksi (BI) skalası uygulandı. Bulgular. Albumin indeksi; ilk iskemik inmesini geçiren hastalarda normalken tekrarlayan iskemik inmesini geçiren grupta hafif yükselmiş olarak saptandı. BOS Ig G/BOS albumin oranı $(0,32 \pm 0,04)$ ile BOS Ig $G$ indeksi(1,13 $\pm 0,16)$ ve BOS Ig G düzeyleri; tekrarlayan iskemik inme geçiren hastalarda ilk iskemik inmesini geçiren gruptakine kıyasla yüksek bulundu. Ayrıca ilk iskemik inme grubunun aksine tekrarlayan iskemik inme geçiren grupta lezyon volümü ile BOS Ig G düzeyleri arasında pozitif yönde anlamlı bir ilişki izlendi $(\mathrm{p}<0,001)$. MRS'na ve BI'ne bakıldığında ise, MRS tekrarlayan iskemik inmesini geçiren grupta daha yüksekken $(\mathrm{p}=0,001)$. Barthel indeksi daha düşük tespit edildi $(\mathrm{p}=0,009)$. Sonuç. Bu sonuçlarlarla tekrarlayan iskemik inme grubunda artmış BOS Ig $\mathrm{G}$ sentezi ve dolayısıyla tekrarlayan iskemik inme fizyopatolojisinde humoral immun sistemin rolü ortaya konulmuştur. Ancak bunun hastaların kliniğindeki, inmenin prognozu ve inmeye bağlı özürlülükteki yeri tartışmalıdır.

Anahtar sözcükler: İskemik inme, beyin omurilik sıvısı, kan beyin bariyeri, intratekal immun globulin sentezi, humoral immun sistem, inflamasyon

Geliş tarihi/Received: September 21, 2014; Kabul tarihi/Accepted: December 04, 2014

\section{*Corresponding author:}

Dr. Aslı Bolayır, Nöroloji Kliniği, Zile Devlet Hastanesi, TR-60400 Tokat. E-mail: asliarslanturk@gmail.com

\section{Introduction}

Strokes are the third most frequent cause of death worldwide [1, 2]. Ischemic strokes constitute $80-85 \%$ of all strokes. However, there is limited knowledge concerning the physiopathology of ischemic strokes. Damage in neurons is encountered in ischemic strokes due to ischemia. As cells start to die signals on the cell surface start to change, necrotic neuron fragments appear and "danger signals" are emitted. Those danger signals cause necrotic tissue fragments' phagocytizing by mast cells (MC) and perivascular macrophages that are present in the brain tissue as well as increased leukocyte transfer to the region. The innate immune elements as microglia, which arrive at the ischemia area, perivascular macrophages, MC's, blood monocytes, dendritic cells (DC) and monocytes cause post-ischemic inflammation by secreting various pro and anti-inflammatory cytokines and chemokine causing infiltration of inflammatory cells [6-12]. Those proinflammatory mediators increase the blood brain barrier (BBB) disorder, which causes infiltration of leukocytes and expression of endothelial adhesion molecules [13]. MC's and DC's also contribute to the adaptive immunity by presenting antigens $[12,14,15]$. Through the blood-brain barrier, which has been disturbed by those pro-inflammatory mediators and chemokine, come $\mathrm{T}$ cells. Those $\mathrm{T}$ cells transform into cytotoxic $\mathrm{T}$ cells or $\mathrm{T}$ helper cells according to the cytokine content of the area. Tissue antigens that have been produced as a result of disintegration of cell membrane and previously had been suppressed by BBB are recognized by the newly arrived B cells. Later a response independent of $\mathrm{T}$ cells or dependent on $\mathrm{T}$ cells that are sensitive to central nervous system (CNS) agents as myelin basic protein or related peptides might develop [16, 17]. By activation of $\mathrm{T}$ cell dependent $\mathrm{B}$ cells, $\mathrm{B}$ cells transform into short living plasma cells and a little amount of immunoglobulin ( Ig) synthesizes antibodies of $M$ isotope [18, 19]. Some B cells, on the other hand, transform into memory B cells and long living plasma cells. Those B cells are capable of producing Ig G, A, M [17]. Some of those memory B cells are located in peripheral blood while some move into the lymphoid tissue and some 
into the ectopic lymphoid structure in CNS (neolymphogenesis) [20]. Those memory B cells produce a quick antibody response in case they encounter the same antigen for a second time $[17,21]$.

Hence, antibodies for CNS antigens are developed following an ischemic stroke. This adaptive immune response has an autoimmune potential against the organ in which cell death has occurred [22]. Inflammation starts right after ischemia, cell mediated immune response peaks in about 24 hours and humoral immune response is produced within 7-10 days $[23,24]$. In case of a second stroke attack, in which necrotic neuron fragments are released, these antigens might get recognized by memory B cells present in the peripheral blood and ectopic lymphoid structure, due to the disturbed BBB. In such a case a quick and big Ig synthesis response might be developed against those antigens.

It is considered that in terms of damage during the acute phase of ischemic strokes cell mediated immune response is relatively more important although the role of humoral immune response is not exactly clarified [23]. Long term effects of humoral immune responses related to strokes as well as their roles in ischemic processes as brain atrophy and dementia are little known $[25,26]$. Similarly, there is no data on whether the immune system develops memory against antigens and autoimmune responses in case of a reappearance of the same antigens, as it might be the case in repeated strokes [26].

This study targets to determine the existence and the amount of immunoglobulin synthesized intrathecally as a result of the immune response following a primary or repeated ischemic stroke. This way the humoral response's effect on the long term prognosis of ischemic strokes might be clarified.

\section{Material and methods}

In this study data collected from 51 patients of 18-90 years of age who came to Ankara Atatürk Training and Research Hospital within the period December 2012-August 2013. The patients had complaints as mental fog, agitation and disorientation. Their lumbar punctures were ordered for differential diagnosis concerning encephalitis/meningitis and diagnosed with ischemic stroke during their long term follow-up.

Cranial tomography's (CCT) or cranial magnetic resonance imaging's (MRI) were taken within the first 24 hours of each patient's complaints. Those who had hemorrhagic components in their images were not included in the study. Lumber puncture was not applied to those who exhibited intracranial pressure increase during cranial imaging and/or neurological examinations, who had high risk of bleeding or who had infections/inflammations in lumber puncture region.

A high level of intrathecal Ig synthesis was not expected in the group with the primary strokes since there was no sensitization in their case yet. On the other hand, a relatively bigger and quicker Ig synthesis was expected in the group with recurrent strokes. Even without sensitization a non-specific Ig synthesis occurs in CSF in the 7-10 days following the first ischemic stroke [23]. In order to avoid the confusion likely to have resulted from those patients who went under lumber puncture within the 72 hours following appearance of their complaints were included from the study. Patients with autoimmune history were excluded on the basis that their condition might increase Ig G, A, M synthesis.

Permissions from patients' themselves or their relatives (legal guardians etc.) were gathered prior to the application of lumber puncture processes.

For encephalitis/meningitis differential diagnosis cells in CSF samples were counted by dripping on thoma lames. The said evaluation was also used for determination of disorders of blood brain barrier BBB in the study.

BOS Ig levels of the patients were evaluated tubulometrically while blood Ig levels, which were taken concurrently, were evaluated nephelometrically. Serum and CSF samples were preserved at -80 degrees centigrade until the kits are acquired. 
Microalbumin values in CSF and albumin values in blood were measured concurrently for albumin index, used for evaluation of BBB's integrity, CSF Ig G index used for determination of intrathecal Ig $\mathrm{G}$ synthesis and for CSF Ig G/albumin ratio calculation.

In determination of repetition of stroke the patient's history and/or detection of chronic ischemic lesions in cranial MRI's or CCT's were used as basis.

In order to measure the volume of ischemic area a region of interest (ROI) was first decided. Sides of lesion areas in each section were drawn by hand and area of the drawn regions were measured automatically by PACS (Picture Archiving and Communication System Software) in $\mathrm{mm}^{2}$ 's. The measured area values were, then, multiplied by the section thickness ( $5 \mathrm{~mm}$ for DAG sections, $2 \mathrm{~mm}$ for BBT sections) and then divided by 1000 in order to get volumes measured in $\mathrm{cm}^{3}$ 's.

For the clinical evaluation of the patients upon admission Glasgow Coma Scale (GCS), National Institute of Health Stroke Scale (NIHSS); upon discharge NIHSS, for determination of impairment Modified Rankin Scale (MRS) and Barthel Index (BI) were applied. In this way relations among Ig levels with NIHSS scores at admission and discharge, MRS and (BI) scores were observed. 3 points or more increases in NIHSS scores were regarded as progression.

Research data were processed by SPSS 15.0 statistical software. Descriptive statistics were presented in terms of $( \pm)$ standard deviation, frequency distribution and percentiles. In addition to those descriptive statistics, compliance with normal distribution was tested to determine differences between the groups. Following the evaluation of the results nonparametric test as Kruskal-Wallis Tests, Spearman Correlation Test and MannWhitney U Test were employed as statistical methods. Statistical level of significance was set at $\mathrm{p}<0.05$.

\section{Results}

Among the 51 the number of patients who had their first strokes was 32, while there were 19 patients with recurrent strokes. Age averages for the groups were $64.75 \pm 1.95$ and $69.61 \pm 2.56$ respectively.

Among the 32 with first time strokes 14 were female and 18 were male while 8 of the 19 patients with recurrent strokes were female and 11 were male.

Data concerning average age, GCS, admission/discharge NIHSS scores, MRS and BI of the two groups are presented in Table 1.

Table 1. Data for average age, GCS, admission/discharge NIHSS scores, MRS and BI scores for patient groups with first time vs. recurrent strokes.

\begin{tabular}{llll}
\hline Variant & First ischemic stroke $(\mathbf{n}=32)$ & Recurrent ischemic stroke $(\mathbf{n}=19)$ & P-Value \\
\hline Age (mean year) & $64.75 \pm 1.95$ & $69.61 \pm 2.56$ & 0.08 \\
Sex & Female count: 14 ; male count: 18 & Female count: 8, male count: 11 & 0.91 \\
Mean GCS & $13.5 \pm 0.65$ & $14.44 \pm 0.38$ & 0.40 \\
Mean admission NIHSS & $3.25 \pm 0.36$ & $4.33 \pm 0.89$ & 0.41 \\
Mean discharge NIHSS & $2.53 \pm 0.40$ & $3.72 \pm 0.90$ & 0.31 \\
Mean MRS & $1.34 \pm 0.19$ & $2.38 \pm 0.24$ & 0.001 \\
Mean Barthel index & $84.84 \pm 2.95$ & $69.16 \pm 5.25$ & 0.009 \\
\hline
\end{tabular}

When the two groups are compared in terms of aforementioned parameters BI was recorded to be lower in the group with recurrent strokes ( $\mathrm{p}=0.009)$ while MRS was seen to be higher $(\mathrm{p}=0.001)$. Other differences between the two groups were not statistically significant.

When lesion volumes are taken into consideration, the average was seen to be $19.48 \pm$ $7.25 \mathrm{~cm}^{3}$ with the group with first-time strokes while that of the second group was recorded as $11.2 \pm 3.32 \mathrm{~cm}^{3}$. Serum albumin, serum Ig G, serum Ig M and serum Ig A values within the group with first-time strokes were realized as $3.97 \pm 0.06 \mathrm{~g} / \mathrm{dL}$, 
$1045.09 \pm 43.08 \mathrm{mg} / \mathrm{dL}, 85.27 \pm 7.57 \mathrm{mg} / \mathrm{dL}, 256.35 \pm 21.54 \mathrm{mg} / \mathrm{dL}$ respectively with the group with first-time strokes. Those of the other group were measured as $3.76 \pm 0.11$ $\mathrm{g} / \mathrm{dL}, 55 \pm 102.11 \mathrm{mg} / \mathrm{dL}, 80 \pm 11.89 \mathrm{mg} / \mathrm{dL}, 260.72 \pm 31.94 \mathrm{mg} / \mathrm{dL}$ respectively.

Data concerning lesion volume, serum albumin, Ig G, Ig M and Ig A average, and CSF albumin, protein, cell count, Ig G, Ig M and Ig A average collected from CSF material acquired from the patients are presented in Table 2.

Table 2. Data for lesion volume, serum albumin, Ig G, Ig M and Ig A average, and CSF albumin, protein, cell count, Ig G, Ig M and Ig A average collected from CSF material acquired from the patients for patient groups with first time vs. recurrent strokes.

\begin{tabular}{llll}
\hline Variant & $\begin{array}{l}\text { First ischemic } \\
\text { stroke }\end{array}$ & $\begin{array}{l}\text { Recurrent } \\
\text { ischemic stroke }\end{array}$ & P-Value \\
\hline Lesion volume $\left(\mathrm{cm}^{3}\right)$ & $19.48 \pm 7.25$ & $11.32 \pm 3.32$ & 0.96 \\
Mean serum albumin (g/dL) & $3.97 \pm 0.06$ & $3.76 \pm 0.11$ & 0.14 \\
Mean serum Ig G (mg/dL) & $1045.09 \pm 43.08$ & $1186.55 \pm 102.11$ & 0.41 \\
Mean serum Ig M (mg/dL) & $85.27 \pm 7.57$ & $99.80 \pm 11.89$ & 0.40 \\
Mean serum Ig A (mg/dL) & $256.35 \pm 21.54$ & $260.72 \pm 31.94$ & 0.89 \\
Mean CSF albumin (mg/dL) & $34.77 \pm 4.86$ & $34.64 \pm 6.92$ & 0.74 \\
Mean CSF protein (mg/dL) & $48.72 \pm 3.71$ & $48.55 \pm 6.79$ & 0.74 \\
CSF cell count (n) & $2.18 \pm 1.32$ & $2.10 \pm 1.63$ & 0.84 \\
Mean CSF Ig G (mg/dL) & $2.28 \pm 0.33$ & $7.34 \pm 0.23$ & $<0.001$ \\
Mean CSF Ig M (mg/dL) & $0.02 \pm 0.00$ & $0.03 \pm 0.00$ & 0.41 \\
Mean CSF Ig A (mg/dL) & $0.01 \pm 0.00$ & $0.02 \pm 0.01$ & 0.82 \\
\hline
\end{tabular}

When the two groups are compared in terms of the above parameters, it is seen that CSF Ig $\mathrm{G}$ levels were higher with the group with recurrent strokes at a statistically significant extent (Figure 1). Differences in other parameters were not statistically significant.

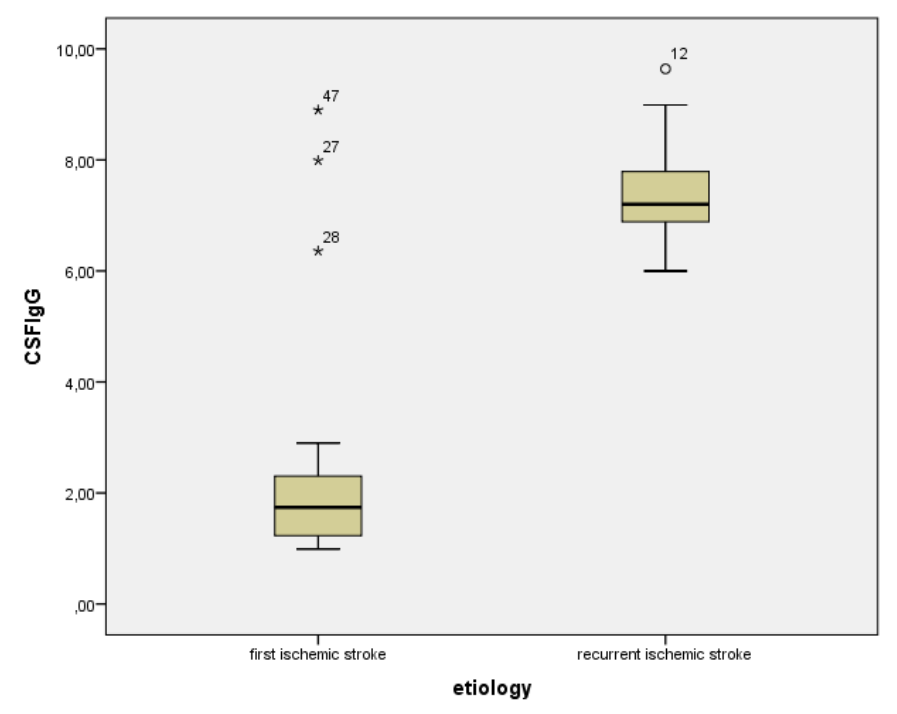

Figure 1. Comparison of CSF Ig G levels with patients with first time vs. recurrent strokes.

When the two groups are evaluated in terms of CSF Ig M and Ig A levels; patients with first time strokes had an average level of CSF Ig M at $0.02 \mathrm{mg} / \mathrm{dL}$ and an average level of CSF Ig A M at $0.01 \mathrm{mg} / \mathrm{dL}$. Those parameters actualized at $0.03 \mathrm{mg} / \mathrm{dL}$ and $0.02 \mathrm{mg} / \mathrm{dL}$, respectively, with the other group. Differences between the two groups in terms of CSF Ig M and Ig A levels were not found to be statistically significant ( $\mathrm{p}=0.41 ; \mathrm{p}=0.82)$.

When CSF Ig M and CSF Ig A levels with serum Ig M and serum Ig A levels were compared; CSF Ig M level was found to be at $0.02 \mathrm{mg} / \mathrm{dL}$ and serum Ig M level was found to be at $85.27 \pm 7.57 \mathrm{mg} / \mathrm{dL}$ with the group with first time strokes and no statistically significant relation was found $(\mathrm{p}=0.70)$. 
CSF Ig A level was found to be at $0.01 \mathrm{mg} / \mathrm{dL}$ and serum Ig A level was found to be at $256.35 \pm 21.54 \mathrm{mg} / \mathrm{dL}$, again, with the group with first time strokes and no statistically significant relation was found ( $\mathrm{p}=0.21$ ). CSF Ig M level was found to be at $0.03 \mathrm{mg} / \mathrm{dL}$ and serum Ig M level was found to be at $99.50 \pm 11.89 \mathrm{mg} / \mathrm{dL}$ with the group with recurrent strokes and no statistically significant relation was found $(\mathrm{p}=0.21)$.

CSF Ig A level was found to be at $0.02 \pm 0.01 \mathrm{mg} / \mathrm{dL}$ and serum Ig A level was found to be at $260.72 \pm 31.94 \mathrm{mg} / \mathrm{dL}$, again, with the group with recurrent strokes and a statistically significant relation was found $(\mathrm{p}=0.03)$.

Albumin indices of patients were calculated by dividing serum albumin levels by CSF albumin levels. Albumin index was recorded as $8.77 \pm 1.25$ with the first-time group and as $9.46 \pm 1.97$ with the recurrent group. The difference was not found to be statistically significant $(\mathrm{p}=0.90)$.

CSF Ig G indices were calculated by dividing CSF Ig G level - serum albumin level ratio by CSF albumin level-serum albumin level ratio. CSF Ig G index was recorded as 0.37 \pm 0.10 with the first-time group and as $1.13 \pm 0.16$ with the recurrent group. The difference was found to be statistically significant $(\mathrm{p}<0.001)$.

When CSF Ig G/CSF albumin ratios are compared this value actualized as $0.09 \pm 0.02$ with the first-time group while the value $0.32 \pm 0.04$ with the recurrent stroke group. CSF Ig G/CSF albumin ratio was significantly larger with the recurent stroke group $(p<0.001)$.

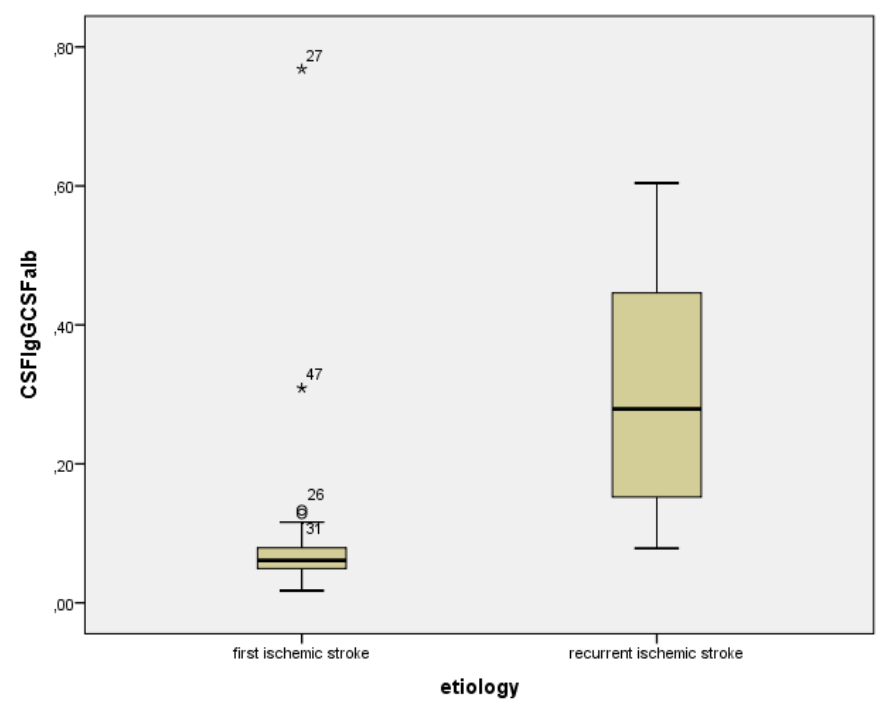

Figure 2. Comparison of first-time vs. Recurrent stroke groups in terms of CSF Ig G/CSF albumin ratio.

When lesion volumes and CSF Ig G values are compared lesion volume was found to be $19.48 \pm 7.25 \mathrm{~mm}^{3}$ and average CSF Ig G level as $2.28 \pm 0.33 \mathrm{mg} / \mathrm{dL}$ with the first-time group. No statistically significant difference was noted $(\mathrm{p}=0.89)$. Lesion volume was found to be $11.32 \pm 3.32 \mathrm{~mm}^{3}$ and average CSF Ig G level as $7.34 \pm 0.23 \mathrm{mg} / \mathrm{dL}$ with the recurrent stroke group. A statistically significant and positive correlation between when lesion volumes and CSF Ig G values was noted with this group $(\mathrm{p}<0.001)$.

\section{Discussion}

Cerebral ischemia triggers many cellular and molecular events as cell death and tissue infarct. Hence, pharmacologic treatments for acute stroke developed in later years fundamentally depend on inflammation $[27,28]$

51 patients with acute stroke attacks, of 18-90 years old were admitted into our study in two groups as first-time strokes vs. recurrent strokes. When the two groups were 
compared in terms of base characteristics (age, sex etc.), GCS and NIHSS scores no significant differences were noted. MRS was recorded to be higher with the recurrent stroke group ( $\mathrm{p}=0.001)$ and BI was found to be larger with the first-time group $(\mathrm{p}=0.09)$. Since MRS is a scoring system used for determination of impairment after a stroke and a higher score signifies a higher level of impairment, the recurrent stroke group is expected to have a higher MRS value. Since BI is also a measure of prognosis and impairment following a stroke, it is expected to be lower with the recurrent stroke group. GCS is a scale used in emergency services to measure consciousness. Patients with low GCS values were excluded in our study due to poor cooperation and difficulty of application of lumbar puncture. Hence, the two groups did not exhibit any significant difference in GCS values. Lower GCS values among the patients included in our study were due to sensorial or sensorimotor aphasia.

Albumin indices were calculated in order to compare BBB functions in the two groups. No statistically significant difference in albumin index values was encountered. However, since an albumin index value of 9 or lower signifies healthy BBB and values of 9-14 mean slight damage it is reasonable to assert that $\mathrm{BBB}$ is healthy within the first-time group, while it is slightly damaged within the recurrent stroke group. This result contradicts with Costantino et al. [13] and Prüss et al. [29], whose studies asserted that there is damage in BBB secondary to a stroke, whether it is a first-time or a recurrent stroke. However, in Strand et al. [30] study albumin levels for transient ischemic attack (TIA) and infarct groups were within the normal interval and close to the upper limit, hence albumin index values were small as they are in our study.

Cell counts from CSF were performed for all patients included in our study in order to evaluate integrity of BI. The results have shown that there were no pleocytosis for either group. When cell counts were compared no statistically significant difference was noted $(\mathrm{p}=0.84)$. This result contradicts with albumin index values, which reflected that BI was slightly damaged in the recurrent stroke group. Furthermore, these findings are do not comply with Sörnas et al. [31] study, which asserted that CSF leukocyte counts increase after 2-3 days following an ischemic stroke, Akopov et al. [32] study, which state that a perfused brain houses a big number of marked polymorphonuclear leukocytes within the first 6-12 hours following an ischemic stroke and Chuaqui et al. [33] study, which suggests there is a dense leukocyte infiltration in brain parenchyma 2-3 days later after a stroke.

In case necrotic CNS antigens produced as a result of brain tissue disintegration during a first-time ischemic stroke does a B cell activation through T cells, memory B cells against these antigens will develop [21]. Hence, synthesis of Ig G, which is a long lasting antibody and which reaches high levels in especially secondary immune response, is expected to have happened within the group that had a stroke secondary to such sensitization. Essentially, CSF Ig G levels within the recurrent stroke group were significantly higher $(\mathrm{p}<0.001)$ than those of the first-time group in our study. However, CSF Ig M levels reflected no such significant difference $(\mathrm{p}=0.41)$. This is due to the fact that Ig $\mathrm{M}$ is the first synthesized Ig and short-living. Ig $\mathrm{M}$ appears 7-10 days after the first sensitization and no significant increase in its levels is encountered in secondary immunity. Since, in our study, lumbar puncture was applied to the patients within 72 hours of their complaints' start no significant differences between Ig M values were noted. No significant difference in Ig A levels were noted $(\mathrm{p}=0.83)$ since brain tissues are not secretory, levels of Ig A, which is present in respiratory, digestive and genital system secretions and tear, saliva, colostrum and milk and which is synthesized in secretory tissues; sub-mucosa plasma cells.

Prüss et al. [29] study produced similar results to our own concerning higher CSF Ig G levels when compared with the general population. The same study mentions oligoclonal Ig G band, high Ig A and Ig M antibody levels with $24.8 \%$ of ischemic stroke patients. Oligoclonal Ig G level is considered to be related to focal cerebral ischemia and CSF- 
specific Ig synthesis. Intrathecal Ig synthesis related to strokes is considered to appear as a result of an unnoted inflammatory condition, previous neuronal tissue's repetitive CNS antibody presentation to the immune system due to its silent ischemic degeneration, or polyclonal non-specific B cell activation secondary to brain damage. The second alternative appears to be more likely for the first-time stroke patients in our study. High oligoclonal band findings in GIA group supports this hypothesis and helps to identify steps prior to the stroke.

Strand et al. [30] study takes Ig G levels taken from a healthy group of same sex and age. The patients went under lumbar punctures twice (on the first and the fifth days of their strokes). They were divided into 3 as GIA, infarct and hemorrhage groups. Ig G levels were found to be in the normal interval and close to the upper limit for the GIA group, while this value were found to be higher than normal for both ischemia and hemorrhage groups ( $\mathrm{p}<0.001)$. Furthermore, Ig $\mathrm{G}$ levels were reported to be significantly higher in the second lumber puncture for all three groups. However, No clear relation between this increase and lesion volume or prognosis [30].

Reiber et al. [34] compared blood and CSF Ig G, Ig A and Ig M levels in order to evaluate BBB. They observed that ischemic stroke patients with albumin indices higher than 9, signifying a disorder in BBB, as blood Ig A and Ig M levels increase BOS Ig A and M levels increase as well. However between CSF Ig G levels there is no such linear relationship even in cases with BBB disorder due to presence of intrathecal synthesis. In our study, when blood Ig G, Ig M and Ig A levels were taken into consideration no significant differences between the two groups were encountered $(\mathrm{p}=0.41 ; \mathrm{p}=0.40$; $\mathrm{p}=0.89$ ). Furthermore, within the first-time group no significant relation was found between serum Ig A and Ig M levels with CSF Ig A and M levels ( $\mathrm{p}=0.21 ; \mathrm{p}=0.70)$. This is considered to be a result of the fact that albumin index is lower than 9, reflecting a healthy BBB, within the first-time group. Within the recurrent stroke group no significant relation between serum Ig M levels and CSF Ig M levels ( $p=0.21$ ). This might be due to the fact that the slight damages in BBB in the recurrent stroke group are not as severe as to allow Ig M, which is a large molecule, through the barrier. However, a significant correlation between serum Ig A levels and CSF Ig A levels was recorded $(\mathrm{p}=0.03)$ within the recurrent stroke group. This, on the other hand might be related to slight damages in the BBB that let Ig A, a relatively small molecule, through.

No significant relation was noted in our study concerning CSF Ig G levels, MRS and BI between the two groups $(\mathrm{p}=0.28 ; \mathrm{p}=0.53)(\mathrm{p}=0.22 ; \mathrm{p}=0.22)$. These results comply with the study stating that mice that lack $\mathrm{T}$ lymphocytes without $\mathrm{B}$ cells or whose $\mathrm{B}$ cells are preserved are safe from ischemic damage [35, 36]. Hence, protection from damage was attributed to $\mathrm{T}$ cells in that study. Therefore, $\mathrm{T}$ cells are considered to have the primary role in inflammation related damage seen in ischemic strokes. The role of B lymphocytes and Ig produced by them in acute inflammation, patients' clinic, prognosis of strokes and impairment due to strokes is debatable. However, humoral immune response related to strokes might be effective in the long-term,roles of factors such as brain atrophy and dementia are little known [13].

In our study we employed CSF Ig G to albumin ratio and CSF Ig G index to evaluate intrathecal Ig $G$ synthesis. Values exceeding 0.27 indicate an increased level of intrathecal Ig G synthesis [37] so it can be asserted that intrathecal Ig G levels in the first stroke group are within normal limits while those in the recurrent stroke group are elevated. Furthermore, CSF Ig G/CSF albumin ratio was found to be significantly higher in the recurrent stroke group $(\mathrm{p}<0.001)$. CSF Ig $\mathrm{G}$ index is expected to have values between $0.28-0.70$. A value higher than 0.70 indicates elevated Ig $G$ synthesis [37]. Therefore, CSF Ig G index values were within the normal interval for the first stroke group while they were found to be elevated in the recurrent stroke group. This situation is consistent with the elevated CSF Ig G/CSF albumin ratio values indicating intrathecal Ig $\mathrm{G}$ synthesis in the recurrent stroke group. Similarly, when the two groups were compared 
in terms of CSF Ig $\mathrm{G}$ indices, average CSF Ig G index values were found to be significantly higher in the recurrent stroke group $(\mathrm{p}<0.001)$, which confirmed our hypothesis indicating that intrathecal Ig $G$ synthesis is increased secondary to sensitization in the recurrent stroke group.

When lesion volumes in the patients included in our study are considered, no significant relation was noted between lesion volumes and CSF Ig G levels in the first stroke group $(\mathrm{p}=0.89)$. This result complies with our finding of no intrathecal Ig G synthesis following the first stroke. When the recurrent stroke group is analyzed, on the other hand, a meaningful relation between lesion volumes and CSF Ig G levels was observed $(\mathrm{p}<0.001)$, which supports the hypothesis that as lesion volumes increase more necrotic tissue disintegration material are produced and those products of disintegration are prone to elevate intrathecal Ig G synthesis in the previously sensitized humoral immune system.

In conclusion, our study has shown that the humoral immune system has a role in the physiopathology of repeated ischemic strokes. However, how important this role is in acute inflammation, patients' clinic, prognosis of strokes and impairment due to strokes is a still a matter of discussion.

Nevertheless, the said humoral immune response might be important in the long-term development of the stroke condition. The risk of developing dementia in patients who have an episode of stroke is significantly higher within the first year following the episode, which continually decreases each year and reduces to $2 \%$ at the end of the 10 th year [38]. Frequency of dementia among stroke patients is $30 \%$. The risk increases with age and magnitude of the stroke. Furthermore, some studies [39-42] have shown a positive correlation between stroke repetition and development of dementia. A similar relation involving the number and magnitude of silent infarcts is also noted [39].

Dementia secondary to strokes is often related to brain atrophy. Cerebral atrophy is regarded a predictor in development of dementia after strokes. The rooting cause of cerebral atrophy is not exactly known, however immunological mechanisms triggered by strokes cannot be excluded. Pathology studies have shown inflammatory infiltrations lasting years after strokes [13].

Treatment options for ischemic strokes, which is an entity that causes substantial healthcare expenses and loss of workforce for patients and their relatives alike, are currently very limited. We are able to suggest that use of humoral immune modulatory agents in the future is a promising alternative for treatment of ischemic strokes, which could prove beneficial for both patients and their relatives.

\section{References}

1. Sacco PL. Vascular diseases. Ed: Merrit, Rowland LP, Merrit's Neurology. Hagerstown. Williams\&Wilkins 2000; 10: 177-85.

2. Raymond D. Adams, Maurice Victor, Allan H. Ropper. Principles of Neurology, 6th edition 777-810.

3. Utku U, Çelik Y. Strokta etyoloji, sınıflandırma ve risk faktörleri. Balkan S: Serebrovaskuler Hastalıklar. Güneş Kitabevi Yayınları, Ankara 2002; 17: 236-55

4. Johnson RT, Griffin JW, McArthur JC, Saver JL. Current Therapy in Neurologic Disease. Sixth edition 2002; 200-6.

5. Badenier MM, Braunersreuther V, Viviani G.L, Dallegri F, Quercioli A, Veneselli E, Mach F, Montecucco F. CC and CXC chemokines are pivotal mediators of cerebral injury in ischaemic stroke. Thrombosis and Haemostasis $2011 ; 105$.

6. Del Zoppo GJ, Schmid-Schonbein GW, Mori E, Copeland BR, Chang CM. Polymorphonuclear leukocytes occlude capillaries following middle cerebral artery occlusion and reperfusion in baboons. Stroke 1991; 22: 1276-83.

7. Ginhoux F. Fate mapping analysis reveals that adult microglia derive from 
primitive macrophages. Science 2010; 330: 841-5.

8. Davalos D. ATP mediates rapid microglial response to local brain injury in vivo. Nat Neurosci 2005; 8: 752-8.

9. Nimmerjahn A, Kirchhoff F, Helmchen F. Resting microglial cells are highly dynamicsurveillants of brain parenchyma in vivo. Science 2005; 308: 1314-8.

10. Mantovani A, Sica A, Locati M. Macrophage polarization comes of age. Immunity 2005; 23: 344-6.

11. Konsman JP, Drukarch B, Van Dam AM. (Peri) vascular production and action of proinflammatory cytokines in brain pathology. Clin Sci 2007; 112: 1-25.

12. Rao KN, Brown MA. Mast cells: Multifaceted immune cells with diverse roles in health and disease. Ann N Y Acad Sci 2008; 1143: 83-104.

13. Iadecola $\mathrm{C}$, Anrather J. The immunology of stroke: From mechanisms to translation. Nat Med 2011; 17: 796-808.

14. Felger JC. Brain dendritic cells in ischemic stroke: time course, activation state, and origin. Brain Behav Immun 2010; 24:724-37.

15. Tanaka R. Migration of enhanced green fluorescent protein expressing bone marrow-derived microglia/macrophage into the mouse brain following permanent focal ischemia. Neuroscience 2003; 117:531-9.

16. Abbas AK, Lichtmman AH, Pillai S. Effector Mechanisms of Humoral İmmunity (7.Bask1) Celluler and Molecular İmmunology.Elsevier Saunders, Philadelphia, ABD 2012; 269-93.

17. Karabudak R. Temel ve Klinik Nöroimmunoloji (1.Bask1).Edinsel İmmunite. 2013; 2767.

18. Abbas AK, Lichtman AH. (2007)Temel İmmunoloji: İmmun sistemin işlev ve bozuklukları.Camcığlu,Y ve Deniz G(Çeviri ed).İstanbul Tıp Kitapevi,İstanbul,s.21-39

19. Abbas AK, Lichtman AH, Pillai S. Cellular and molecular immunology. 7th edition. Elsevier Sauders, Philadelphia, 2012; 55-88.

20. Badenier MM, Braunersreuther V, Viviani GL, Dallegri F, Quercioli A, Veneselli E, Mach F, Montecucco F. CC and CXC chemokines are pivotal mediators of cerebral injury in ischaemic stroke. Thrombosis and Haemostasis 2011; 105.

21. Abbas, AK, Lichtmman AH, Pillai S. Activation of T lmphocytes Celluler and Molecular İmmunology.Elsevier Saunders,Philadelphia, ABD 2012; 203-25.

22. Kono H, Rock KL. How dying cells alert the immune system to danger. Nat Rev Immunol 2008.

23. Abbas, AK. Basic Immunology Updated Edition: Functions and Disorders of the Immune System. Saunders 2010.

24. Yilmaz A. Transient decrease in circulating dendritic cell precursors after acute stroke: potential recruitment into the brain. Clin Sci 2010; 118:147-57.

25. Becker KJ, Kindrick DL, Lester MP, Shea C, Ye ZC. Sensitization to brain antigens after stroke is augmented by lipopolysaccharide. J Cereb Blood Flow Metab 2005; 25: 1634-44.

26. Balkan S. Serebral vasküler anatomi. İç: Klinik Nöroloji. Oğul E 2002: 3-15.

27. Şener RN. Diffusion MRI: Apperent diffusion coefficient (ADC) values in the normal brain, and a classification of brain disorders based on ADC values.Comput Met Imaging Graph 2001; 25: 299-326.

28. Harald P, Deetje I, Baldinger T. Evidence of intrathecal immunoglobulin synthesis in stroke. Arch Neurol 2012; 69: 714-7.

29. Strand T, Alling C, Karlsson B, Karlsson I, Winblad B. Brain and plasma proteins in spinal fluid as markers for brain damage and severity of stroke. Stroke 1984; 15: 138-44.

30. Sörnas R, Ostlund H, Muller R. Cerebrospinal fluid cytology after stroke. Arch Neurol 1972; 26: 489-501.

31. Akopov SE, Simonian NA, Grigorian GS. Dynamics of polymorphonuclear leukocyte accumulation in acute cerebral infarction and their correlation with 
brain tissue damage. Stroke 1996; 27: 1739-43.

32. Chuaqui R, Tapia J. Histologic assessment of the age of recent brain infarcts in man. J Neuropathol Exp Neurol 1993; 52: 481-9.

33. Reiber H, Lange P. Quantification of virus-specific antibodies in cerebrospinal fluid and serum: Sensitive and specific detection of antibody synthesis in brain. Clin Chem 1991; 37: 1153-60.

34. Hurn PD. T-and B-cell-deficient mice with experimental stroke have reduced lesion size and inflammation. J Cereb Blood Flow Metab 2007; 27: 1798-805.

35. Kleinschnitz C. Early detrimental T-cell effects in experimental cerebral ischemia are neither related to adaptive immunity nor thrombus formation. Blood 2010; 115: 3835-42.

36. Thompson EJ. Proteins of the cerebrospinal fluid. Elsevier, London 2005.

37. Leys D, He'non H, Mackowiak-Cordoliani MA, Pasquier F. Poststroke dementia. Lancet Neurol 2005; 4: 752-9.

38. Tatemichi TK, Foulkes MA, Mohr JP, Hewitt JR, Hier DB, Price TR, Wolf PA. Dementia instroke survivors in the stroke data bank cohort: Prevalence, incidence, risk factors and computed tomographic findings. Stroke 1990; 21: 85866.

39. Lin JH, Lin RT, Tai CT, Hsieh CL, Hsiao SF, Liu CK. Prediction of poststroke dementia. Neurology 2003; 61: 343-8.

40. Mok VC, Wong A, Lam WW, Fan YH, Tang WK, Kwok T, Hui AC, Wong KS. Cognitive impairment and functional outcome after stroke associated with small vessel disease. J Neurol Neurosurg Psychiatry 2004; 75: 560-6.

41. Zhou DH, Wang JY, Li J, Deng J, Gao C, Chen M. Study on frequency and predictors of dementia after ischemic stroke: the Chongqing stroke study. J Neurol 2004; 251: 421-7. 